\title{
Breeding Practices and Trait Preferences of Sheep Farmers in a Sub-Humid Tropical Environment
}

\author{
A. Yakubu ${ }^{\mathrm{a}, *}$, S. Isa ${ }^{\mathrm{a}}$, O. Alabi ${ }^{\mathrm{b}}$, A. J. Shoyombo ${ }^{\mathrm{b}}$, \& A. I. Adeolu ${ }^{\mathrm{c}}$ \\ ${ }^{a}$ Department of Animal Science, Faculty of Agriculture, Nasarawa State University, \\ Keffi, Shabu-Lafia Campus, P.M.B. 135, Lafia, 950101, Nigeria \\ bDepartment of Animal Science, Landmark University, Omu-Aran, Kwara, Nigeria \\ 'Department of Agriculture (Animal Science Programme), Alex-Ekwueme Federal University, \\ Ndufu-Alike, P.M.B. 1010, Abakaliki, Ebonyi State, Nigeria \\ "Corresponding author: abdulmojyak@gmail.com; abdulkubu@nsuk.edu.ng \\ (Received 29-09-2019; Revised 10-03-2020; Accepted 23-04-2020)
}

\begin{abstract}
The present study was carried out to determine the livestock breeding practices and the trait preferences of sheep farmers in Nasarawa State, Nigeria. A total of 132 sheep keepers were randomly sampled out of which data from 120 farmers were utilized in the final analysis. Primary data were collected through individual semi-structured questionnaire administration. Categorical and continuous variables including production and breeding traits were statistically tested based on sex of the respondents. Age of respondents, educational status, primary occupation, access to credit, and type of landholding were significantly different between the male and female farmers. Flock size was higher in farms owned by male farmers $(19.63 \pm 1.04$ versus $15.16 \pm 1.00)$. However, both sexes did not differ ( $p>0.05)$ in the ranking of meat, religion, income, hides, and skin and cultural purpose as reasons for keeping sheep. As regards management of sheep, control of breeding and access to veterinary services were low among female farmers. Apart from cultural/religious significance which was ranked higher by female farmers (63.38 versus $52.23 ; \mathrm{p} \leq 0.05)$, other production traits such as disease resistance, survivability, growth rate, meat quality, fertility, body size, and prolificacy did not vary between sexes. Disease resistance, which the male farmers attached more importance $\mathbf{5 7 . 0}$ versus 70.52; $\mathbf{p} \leq 0.05$ ), was the only significant breeding trait between sexes. Categorical principal component analysis (CATPCA) also revealed little influence of sex on the production and breeding traits investigated. The present findings could guide interventions such as the setting up of sustainable community-based breeding schemes to improve sheep production in the study area.
\end{abstract}

Keywords: sex; breeding strategies; ranking; sheep

\section{INTRODUCTION}

Livestock is a major source of livelihood of the rural populace (Parmawati et al., 2018; Anwar et al., 2019). As a result of the involvement of both men and women in livestock keeping, there is a need for a proper comprehension of the traditional breeding practices and trait preferences involving both sexes. This might be exploited in mapping out appropriate strategies to boost livestock production at the village level. It has been reported that in addition to their traditional domestic responsibilities, women had more animals to milk and more productive land to tend (Karmebäck et al., 2015). The objectives of men and women pastoralists for keeping different types of livestock have been reported in Marshall et al. (2014) for sheep and some other livestock species. Different from the conventional top-down approach, community-based breeding programs take into account the indigenous knowledge of the communities on breeding practices and breeding objectives (Tabbaa \& Al-Atiyat, 2009; Gizaw et al., 2013; Wurzinger et al., 2013; Oseni et al., 2017; Mataveia et al., 2018). When such breeding strategies take into account the peculiarities of male and female farmers, there is a probability of achieving better results.

In Nigeria, sub-Saharan Africa, with a total sheep population of 42,500,000 (FAOSTAT, 2017), there is a dearth of information on the traditional breeding practices of sheep farmers in trait preferences and selection of animals for breeding purpose. Sheep farming (especially fattening operations) at low, medium, and commercial scales is fast evolving. However, production and productivity at smallholders' levels are still low. This warrants the need for a systematic selection and breeding scheme. The establishment of a specific breeding program requires a good understanding of the farming system, institutional organizations, and roles before genetic improvement activities. The objective of this study, therefore, was to assess the management practices being embarked upon by male and female sheep farmers in Nasarawa State, north-central Nigeria to better understand the prevailing production systems and breeding programs. 


\section{MATERIALS AND METHODS}

\section{Description of the Study Area}

The study was carried out in Nasarawa State, north-central Nigeria. The State is located within the southern guinea savannah agro-ecological zone and is found between latitudes $7^{\circ} 52^{\prime} \mathrm{N}$ and $8^{\circ} 56^{\prime} \mathrm{N}$ and longitudes $7^{\circ} 25^{\prime} \mathrm{E}$ and $9^{\circ} 37^{\prime} \mathrm{E}$, respectively (Lyam, 2007). A detailed description of the zone has been reported in an earlier study (Yakubu et al., 2019).

\section{Sampling Procedure}

Sheep keepers were selected from the study area (Nasarawa State) based on sheep production potential and willingness of the farmers to participate in this research. A total of 132 sheep keepers were randomly sampled in the study area covering the three Senatorial districts of Nasarawa South (30 males and 14 females), Nasarawa North (30 males and 14 females) and Nasarawa West (30 males and 14 females) using random number generator. However, due to incomplete information in some of the filled questionnaires, analysis of data was restricted to information obtained from 120 sheep keepers (89 males and 31 females) distributed as follows: Nasarawa South (30 males and 11 females), Nasarawa North (30 males and 11 females) and Nasarawa West (29 males and 9 females). In the conduct of the research, there was a strict adherence to the International Ethical Guidelines for Biomedical Research (CIOMS, 2002) involving Human Subjects and the Global code of conduct for research in resource-poor settings following the Convention on Biological Diversity and Declaration of Helsinki.

\section{Data Collection Procedure}

Information was obtained on the socio-economic characteristics of the farmers, ownership of livestock, size and structure of the flock, feeding strategies, health, and other routine management practices as well as production performance. The sheep farmers (both sexes) were asked separately to list the production objectives (reasons for rearing sheep) and rank them using the following criteria: 1 , most important; 2 , more important; 3, important; and 4, least important. They were also asked to list the selection criteria separately for production and breeding traits and ranked them as follows: Ratings of 1 for most preferred, 2 more preferred, 3 preferred, and 4 less preferred. The semi-structured questionnaires were pre-tested on ten (10) sheep farmers in each location to ensure that the questions were adapted to the prevailing local conditions following the description of Dossa et al. (2015) and adopted by Yakubu \& Achapu (2016).

\section{Statistical Analysis}

Between-sexes comparisons of the categorical variables were done using Fisher's Exact Test. Proportions (\%) of individuals in each sheep breed were also calculated as described by Amare et al. (2018). Arithmetic means ( \pm S.E.) of the continuous variables between sexes (gender) were subjected to T-Test. Mean ranks were also calculated for between-sexes comparisons of the production and breeding traits. For comparison between genders, the Kruskal-Wallis test followed by the Mann-Whitney U test for separation of mean ranks was used as described by Dossa et al. (2015) and Yakubu et al. (2019).

To explore hidden relationships among the production as well as breeding traits for appropriate grouping of the respondents based on sex, categorical principal component analysis (CATPCA) procedure was employed. This was as described by Martin-Collado et al., (2015). In this analysis, sex was inputted as a supplementary variable. The PCs were extracted based on Eigenvalues greater than 1 criterion. The PC matrix was rotated using the varimax criterion with Kaiser Normalization to facilitate easy interpretation of the analysis. The PCA reliability was tested using Chronbach's Alpha. SPSS (2015) statistical package was employed in all analyses.

\section{RESULTS}

Education status, primary occupation, access to credit, type of landholding, and age of respondents were significantly $(p \leq 0.01 ; p \leq 0.05)$ higher among the male compared to female farmers (Table 1). There were no significant differences in marital status, personal savings, household size, farm size, and experience in sheep keeping between sexes.

As at the time of the survey, the average flock size $(19.63 \pm 1.04$ versus $15.16 \pm 1.00)$ was significantly $(p \leq 0.05)$ higher in herds owned by male farmers compared to their female counterparts (Table 2). Breed-wise, however, the number of Yankasa, Uda, and Balami did not vary between sexes. Proportionally, there are more breeding animals in Yankasa [Rams:milking ewes:nonmilking ewes of 16.7:19.1:15.4 (male farmers) and 16.7:18.1:16.5 (female farmers)] and Uda sheep [Rams:milking ewes:non-milking ewes of 19.0:16.8:12.4 (male farmers) and 31.7:21.3:15.9 (female farmers)].

The ranking of meat, religion, income, hides and skin, and cultural purpose as reasons for sheep keeping was not significantly different in both sexes (Table 3). Breeding control and access to veterinary were significantly $(\mathrm{p}<0.05 ; \mathrm{p}<0.01)$ higher among males compared to female farmers (Table 4). There were no significant sex differences in the source of foundation stock, management system, feed supplementation, and the number of foundation stock.

From the productivity records overtime, there were no significant sex differences in average age at first parturition (Table 5). However, the average life span (years) of Yankasa, Uda and West African Dwarf sheep were significantly $(p<0.05 ; p<0.01)$ higher in flocks owned by male farmers.

Considering production traits between sexes; body size, growth rate, survival, disease resistance, fertility, prolificacy, and meat quality mean ranks were not significantly influenced (Table 6). However, cultural sig- 
Table 1. Socio economic characteristics of sheep farmers in Nasarawa State

\begin{tabular}{|c|c|c|c|c|}
\hline \multirow{3}{*}{ Characteristics } & \multicolumn{2}{|c|}{ Sex } & \multirow{3}{*}{ Exact significance } & \\
\hline & Male & Female & & \\
\hline & No $(\%)$ & No $(\%)$ & & \\
\hline \multicolumn{5}{|l|}{ Categorical variables } \\
\hline \multicolumn{5}{|l|}{ Marital Status } \\
\hline Single & $18(20.2)$ & $8(25.8)$ & & \\
\hline Married & $71(79.8)$ & $23(74.2)$ & & \\
\hline Widowed & $0(0.0)$ & $0(0.0)$ & $0.613 \mathrm{~ns}$ & \\
\hline \multicolumn{5}{|l|}{ Education } \\
\hline None & $11(12.4)$ & $12(38.7)$ & & \\
\hline Primary & $9(10.1)$ & $4(12.9)$ & & \\
\hline Secondary & $26(29.2)$ & $6(19.4)$ & & \\
\hline Tertiary & $43(48.3)$ & $9(29.0)$ & $0.01^{* *}$ & \\
\hline \multicolumn{5}{|l|}{ Primary occupation } \\
\hline Livestock rearing & $22(24.7)$ & $4(12.9)$ & & \\
\hline Crop farming & $20(22.5)$ & $13(41.9)$ & & \\
\hline Trading & $9(10.1)$ & $2(6.5)$ & & \\
\hline Artisan & $30(33.7)$ & $2(6.5)$ & & \\
\hline Civil Service & $8(9.0)$ & $10(32.3)$ & $0.01^{* *}$ & \\
\hline \multicolumn{5}{|l|}{ Access to Credit } \\
\hline No & $27(30.3)$ & $0 \quad(0.0)$ & & \\
\hline Yes & $62(69.7)$ & $31(100.0)$ & $0.01^{* *}$ & \\
\hline \multicolumn{5}{|l|}{ Personal savings } \\
\hline No & $61(68.5)$ & $16(51.6)$ & & \\
\hline Yes & $28(31.5)$ & $15(48.4)$ & $0.127^{\mathrm{ns}}$ & \\
\hline \multicolumn{5}{|l|}{ Type of landholding } \\
\hline Individual ownership & $60(67.4)$ & $19(61.3)$ & & \\
\hline Communal farming system & $11(12.4)$ & $1(3.2)$ & & \\
\hline Rent & $9(10.1)$ & $1(3.2)$ & & \\
\hline Free occupation & $9(10.1)$ & $10(32.3)$ & $0.02^{*}$ & \\
\hline \multicolumn{5}{|l|}{ Continuous variables } \\
\hline & Mean & Mean & Standard error & $\mathrm{p}$-value \\
\hline Age of respondent (years) & 43.69 & 38.00 & 1.19 & $0.035^{*}$ \\
\hline Household size & 9.83 & 7.68 & 0.82 & $0.250^{\text {ns }}$ \\
\hline Farm size (hectares) & 0.49 & 0.40 & 0.03 & $0.102^{\text {ns }}$ \\
\hline Experience in sheep keeping (years) & 10.29 & 7.95 & 0.68 & $0.132^{\text {ns }}$ \\
\hline
\end{tabular}

Note: $\mathrm{No}=$ Number of respondents; ${ }^{*}=$ Significant at $\mathrm{p} \leq 0.05 ; * *$ Significant at $\mathrm{p} \leq 0.01 ; \mathrm{ns}=$ Not significant.

nificance was rated higher by the female farmers (52.23 versus 63.38; $\mathrm{p} \leq 0.05)$.

Body size, body conformation, mothering ability, survival, heat tolerance, fertility, and temperament were rated the same by both sexes as breeding criteria (Table 7). However, disease resistance was rated higher $(p \leq 0.05)$ by the male farmers compared to their female counterparts.

As regards production traits, two principal components (PCs) were extracted which explained 49.4\% of the variability in the dataset (Figure 1). The first PC $($ Eigenvalue $=2.052)$ explained $25.6 \%$ of the total variance and was greatly determined by cultural/religious significance $(0.878)$, survivability $(0.717)$, disease resistance $(0.641)$, and meat quality $(-0.540)$. The second PC $($ Eigenvalue $=1.902)$ accounted for $23.8 \%$ of the total variance and had its loadings for prolificacy (-0.809), body size (0.631), fertility (0.551) and growth rate $(0.487)$
(Figure 2). The contributions of sex of farmers to both PC1 (-0.132) and PC2 (0.042) in terms of loadings were very low. The high Cronbach's Alpha value of 0.854 indicates the reliability of the CATPCA.

Concerning breeding traits, two PCs were also extracted which accounted for $60.1 \%$ of the observed variation in the dataset (Figure 3). The first PC with an Eigenvalue of 2.793 contributed $34.9 \%$ to the total variance. It was mostly influenced by temperament (0.878), heat tolerance $(0.849)$, disease resistance $(0.818)$, and fertility (0.694). The second PC, with an Eigenvalue of 2.014 and $25.2 \%$ contribution to the variance total, was characterized by body conformation (0.778), mothering ability (0.744), survivability (0.740), and body size (0.538) (Figure 4). Sex of farmers had very low loadings on PC1 (0.018), and PC2 (-0.080), respectively. The Cronbach's Alpha value of 0.905 was high enough to confer reliability to the CATPCA. 
Table 2. Flock structure (Mean \pm S.E.) and proportion (\%) of sheep kept in Nasarawa State

\begin{tabular}{|c|c|c|c|c|}
\hline \multirow{2}{*}{ Parameters } & \multicolumn{2}{|r|}{ Sex } & \multirow{2}{*}{ T-value } & \multirow{2}{*}{ p-value } \\
\hline & Male & Female & & \\
\hline \multicolumn{5}{|l|}{ Flock structure } \\
\hline Flock size (head) & $19.63 \pm 1.04$ & $15.16 \pm 1.00$ & 2.398 & $0.018^{*}$ \\
\hline Yankasa (head) & $16.13 \pm 0.98$ & $13.52 \pm 0.93$ & 1.502 & $0.136^{\mathrm{ns}}$ \\
\hline Uda (head) & $3.15 \pm 0.53$ & $1.64 \pm 0.42$ & 1.599 & $0.112^{\text {ns }}$ \\
\hline Balami (head) & $0.15 \pm 0.11$ & $0.00 \pm 0.00$ & 0.757 & $0.451^{\mathrm{ns}}$ \\
\hline West African Dwarf (head) & $0.20 \pm 0.00$ & $0.00 \pm 0.00$ & 0.623 & $0.535^{\mathrm{ns}}$ \\
\hline \multicolumn{5}{|l|}{ Proportion (\% of the flock) } \\
\hline \multicolumn{5}{|l|}{ Yankasa } \\
\hline Male lambs:female lambs & $12.2: 12.7$ & 12.2:13.1 & & \\
\hline Male yearlings:female yearlings & $10.7: 13.2$ & 8.6:12.2 & & \\
\hline Rams:milking ewes:non-milking ewes & 16.7:19.1:15.4 & 16.7:18.1:16.5 & & \\
\hline Castrates & 0.7 & 1.2 & & \\
\hline \multicolumn{5}{|l|}{ Uda } \\
\hline Male lambs:female lambs & 13.3:13.3 & $9.8: 14.0$ & & \\
\hline Male yearlings:female yearlings & $8.6: 16.2$ & 1.8:9.8 & & \\
\hline Rams:milking ewes:non-milking ewes & 19.0:16.8:12.4 & 31.7:21.3:15.9 & & \\
\hline Castrates & 0.6 & 0 & & \\
\hline \multicolumn{5}{|l|}{ Balami } \\
\hline Male lambs:female lambs & 15.2:23.1 & 0 & & \\
\hline Male yearlings:female yearlings & 0 & 0 & & \\
\hline Rams:milking ewes:non-milking ewes & 23.1:15.2:15.2 & 0 & & \\
\hline Castrates & 7.7 & 0 & & \\
\hline \multicolumn{5}{|l|}{ West African Dwarf } \\
\hline Male lambs:female lambs & 33.3:11.1 & 0 & & \\
\hline Male yearlings:female yearlings & 5.6:0 & 0 & & \\
\hline Rams:milking ewes:non-milking ewes & 16.7:31.7:0 & 0 & & \\
\hline Castrates & & 0 & & \\
\hline
\end{tabular}

Note: S.E. $=$ standard error; ${ }^{*}=$ Significance at $\mathrm{p} \leq 0.05$.

Table 3. Mean ranks of reasons for keeping sheep based on sex and their significance level according to Kruskall-Wallis test ${ }^{\mathrm{y}}$

\begin{tabular}{|c|c|c|c|c|}
\hline \multirow{2}{*}{ Traits } & \multicolumn{2}{|c|}{ Sex } & \multirow{2}{*}{ Kruskall-Wallis test } & \multirow{2}{*}{ Asymptotic significance } \\
\hline & Male & Female & & \\
\hline Meat & 59.45 & 63.52 & 0.344 & $0.557^{\mathrm{ns}}$ \\
\hline Religion & 57.34 & 69.56 & 3.250 & $0.071^{\mathrm{ns}}$ \\
\hline Income & 61.97 & 56.27 & 1.025 & $0.311^{\mathrm{ns}}$ \\
\hline Hides and Skin & 59.69 & 62.84 & 0.226 & $0.635^{\mathrm{ns}}$ \\
\hline Cultural & 62.30 & 55.34 & 1.058 & $0.304^{\mathrm{ns}}$ \\
\hline
\end{tabular}

Note: $y=$ The lower the mean rank, the more important the trait; ns= Not significant.

\section{DISCUSSION}

The larger flock size of male farmers may be attributed to enough time devoted to sheep rearing being their primary occupation, unlike their female counterparts who were mostly into crop farming. The better educational standard, breeding control, and more access to credit and veterinary personnel of men in the present could have also impacted positively on flock size. It is possible that if more women are well educated, can control mating to some extent with access to credit and veterinary services, they will be able to handle large herds. It has been reported that men are given more equitable conditions than women (Boogaard et al., 2015). Therefore, there is a need for interventions geared to- wards improving the lots of female farmers to increase flock size and the associated farm income. In a related study, Aldosari (2018) reported that male herders were more actively involved in sheep keeping, received more benefits and services offered by veterinary clinics, which proved more beneficial for them in terms of larger flock size and profitability. The average flock size obtained in this study is higher than the $8.2 \pm 2.05$ and $11.3 \pm 1.27$ mean values reported by Edea et al. (2012). However, it is lower than the range of 1-300 sheep reported by Marshall et al. (2016), 150 breeding ewes by Bohan et al. (2017), 23.0-31.6 sheep submitted by Getachew et al. (2010) and an average of 22.6 sheep given by Amare et al. (2018). The differences might be attributed to genetic factors, production objectives, available resources, climate and 
Table 4. Management systems of sheep kept in Nasarawa State

\begin{tabular}{|c|c|c|c|c|}
\hline \multirow{3}{*}{ Characteristics } & \multicolumn{2}{|c|}{ Sex } & \multirow{3}{*}{ Exact significance } & \\
\hline & Male & Female & & \\
\hline & No $(\%)$ & No $(\%)$ & & \\
\hline \multicolumn{5}{|l|}{ Categorical variables } \\
\hline \multicolumn{5}{|l|}{ Source of foundation stock } \\
\hline Inherited & $22(24.7)$ & $13(41.9)$ & & \\
\hline Purchase from market & $46(51.7)$ & $13(41.9)$ & & \\
\hline Purchase from neighbour & $10(11.2)$ & $2(6.5)$ & & \\
\hline Borrowed & $8(9.0)$ & $2(6.5)$ & & \\
\hline Others & $3(3.4)$ & $1(3.2)$ & $0.487^{\mathrm{ns}}$ & \\
\hline \multicolumn{5}{|l|}{ Management system } \\
\hline Semi-intensive & $65(73.0)$ & $20(64.5)$ & & \\
\hline Intensive & $8(9.0)$ & $2(6.5)$ & & \\
\hline Extensive & $16(18.0)$ & $9(29.0)$ & $0.404^{\mathrm{ns}}$ & \\
\hline \multicolumn{5}{|l|}{ Feed supplementation } \\
\hline Yes & $66(74.2)$ & $18(58.1)$ & & \\
\hline No & $23(25.8)$ & $13(41.9)$ & $0.113^{\text {ns }}$ & \\
\hline \multicolumn{5}{|l|}{ Breeding control } \\
\hline No & $72(80.9)$ & $30(96.8)$ & & \\
\hline Yes & $17(19.1)$ & 1 (3.2) & $0.040^{*}$ & \\
\hline \multicolumn{5}{|l|}{ Access to vet } \\
\hline Yes & $78(87.6)$ & $19(61.3)$ & & \\
\hline No & $11(12.4)$ & $12(38.7)$ & $0.003^{* *}$ & \\
\hline \multicolumn{5}{|l|}{ Continuous variable } \\
\hline & Mean \pm S.E. & Mean \pm S.E. & T-value & p-value \\
\hline No of foundation stock & $2.67 \pm 0.17$ & $3.25 \pm 0.69$ & -1.174 & $0.243^{\text {ns }}$ \\
\hline
\end{tabular}

Note: $\mathrm{No}=$ Number of respondents; ${ }^{*}=$ Significant at $\mathrm{p}<0.05 ;{ }^{* *}=$ Significant at $\mathrm{p}<0.01 ; \mathrm{ns}=$ not significant; S.E. $=$ standard error.

Table 5. Productivity indices (Mean \pm S.E.) of sheep kept in Nasarawa State

\begin{tabular}{lcccc}
\hline \multirow{2}{*}{ Parameters } & \multicolumn{2}{c}{ Sex } & T-value & p-value \\
\cline { 2 - 3 } & Male & Female & & \\
\cline { 2 - 3 } $\begin{array}{l}\text { Average age at first parturition (months) } \\
\text { Yankasa }\end{array}$ & $13.77 \pm 0.49$ & $15.24 \pm 0.66$ & -1.748 & $0.084^{\text {ns }}$ \\
Uda & $15.85 \pm 0.93$ & $15.24 \pm 1.03$ & 0.447 & $0.657^{\text {ns }}$ \\
Balami & $15.82 \pm 0.84$ & $15.63 \pm 1.28$ & 0.131 & $0.897^{\text {ns }}$ \\
West African Dwarf & $15.24 \pm 1.10$ & $15.42 \pm 1.21$ & -0.120 & $0.905^{\text {ns }}$ \\
Average life span (years) & & & \\
Yankasa & $8.17 \pm 0.30$ & $5.14 \pm 0.32$ & 6.824 & $0.000^{* *}$ \\
Uda & $8.67 \pm 0.35$ & $7.44 \pm 0.41$ & 2.245 & $0.031^{*}$ \\
Balami & $8.79 \pm 0.51$ & $7.90 \pm 0.56$ & 1.278 & 0.216 ns \\
West African Dwarf & $6.93 \pm 0.61$ & $4.31 \pm 0.49$ & 3.381 & $0.002^{* *}$ \\
\hline
\end{tabular}

Note: S.E. $=$ standard error; ${ }^{*}=$ Significant at $\mathrm{p}<0.05 ;{ }^{* *}=$ Significant at $\mathrm{p}<0.01$.

ecology, and management practices. The seemingly better management practices adopted by male herders in the current study could have influenced the higher average life span of the animals.

The present study revealed the multi-functionality (meat, religion, income, hides and skin, and cultural purpose) of sheep in the study area. This is congruous to the submission of Dossa et al. (2015). Income as a reason for rearing sheep by both sexes in the current study might be attributed to its veritable role in meeting the family needs of the farmers. The more the income of the farmer, there is every possibility for him/her to increase purchasing power. The social status and capital asset of the farmer could also be boosted as a result of improvement in financial worth. This highest rating of income is consistent with the findings of Edea et al. (2012). Similarly, Marshall et al. (2014) gave savings and insurance purposes as possible reasons pastoralists embark on livestock farming.

The higher preference for cultural/religious significance as a production trait by the female sex is in tandem with the current observation on the reasons why sheep were kept. This might not be unconnected with the more premium attached to this trait by the female 
Table 6. Mean ranks of traits preferred for production of sheep obtained from Kruskall-Wallis testy

\begin{tabular}{|c|c|c|c|c|}
\hline \multirow{2}{*}{ Traits } & \multicolumn{2}{|c|}{ Sex } & \multirow{2}{*}{ Kruskall-Wallis test } & \multirow{2}{*}{$\begin{array}{l}\text { Asymptotic } \\
\text { significance }\end{array}$} \\
\hline & Male & Female & & \\
\hline Body size & 59.53 & 63.27 & 0.329 & $0.566^{\mathrm{ns}}$ \\
\hline Growth rate & 60.38 & 60.84 & 0.005 & $0.943^{\text {ns }}$ \\
\hline Cultural/Religious significance & $63.38^{b}$ & $52.23^{\mathrm{a}}$ & 4.008 & $0.045^{*}$ \\
\hline Survival & 60.53 & 60.40 & 0.000 & $0.983^{\text {ns }}$ \\
\hline Disease resistance & 60.65 & 60.06 & 0.011 & $0.918^{\text {ns }}$ \\
\hline Fertility & 60.68 & 59.98 & 0.011 & $0.916^{\text {ns }}$ \\
\hline Prolificacy & 62.41 & 55.02 & 1.122 & $0.290^{\text {ns }}$ \\
\hline Meat quality & 58.31 & 66.79 & 1.660 & $0.198^{\text {ns }}$ \\
\hline
\end{tabular}

Note: Means in the same row with different superscripts differ significantly $(\mathrm{p} \leq 0.05)$. $\mathrm{y}=$ The lower the rank mean, the more important the trait; ${ }^{*}=$ Significance at $\mathrm{p} \leq 0.05 ; \mathrm{ns}=$ Not significant.

Table 7. Mean ranks of factors preferred in the choice of breeding stock of sheep and their significance levels according to KruskallWallis testy

\begin{tabular}{|c|c|c|c|c|}
\hline \multirow{2}{*}{ Traits } & \multicolumn{2}{|c|}{ Sex } & \multirow{2}{*}{ Kruskall-Wallis test } & \multirow{2}{*}{$\begin{array}{l}\text { Asymptotic } \\
\text { significance }\end{array}$} \\
\hline & Male & Female & & \\
\hline Body size & 62.83 & 53.82 & 1.798 & $0.180^{\text {ns }}$ \\
\hline Body conformation & 59.44 & 63.55 & 0.350 & $0.554^{\mathrm{ns}}$ \\
\hline Mothering ability & 62.87 & 53.71 & 1.780 & $0.182^{\mathrm{ns}}$ \\
\hline Survivability & 59.70 & 62.79 & 0.198 & $0.656^{\text {ns }}$ \\
\hline Heat tolerance & 59.73 & 62.71 & 0.195 & $0.659^{\text {ns }}$ \\
\hline Disease resistance & $57.01^{\mathrm{a}}$ & $70.52^{\mathrm{b}}$ & 4.175 & $0.041^{*}$ \\
\hline Fertility & 58.43 & 66.44 & 1.714 & $0.190^{\mathrm{ns}}$ \\
\hline Temperament & 61.31 & 58.16 & 0.224 & $0.636^{\mathrm{ns}}$ \\
\hline
\end{tabular}

Note: Means in the same row with different superscripts differ significantly $(\mathrm{p} \leq 0.05)$. $\mathrm{y}=$ The lower the rank mean, the more important the trait; ${ }^{*}=$ Significance at $\mathrm{p} \leq 0.05 ; \mathrm{ns}=$ Not significant.

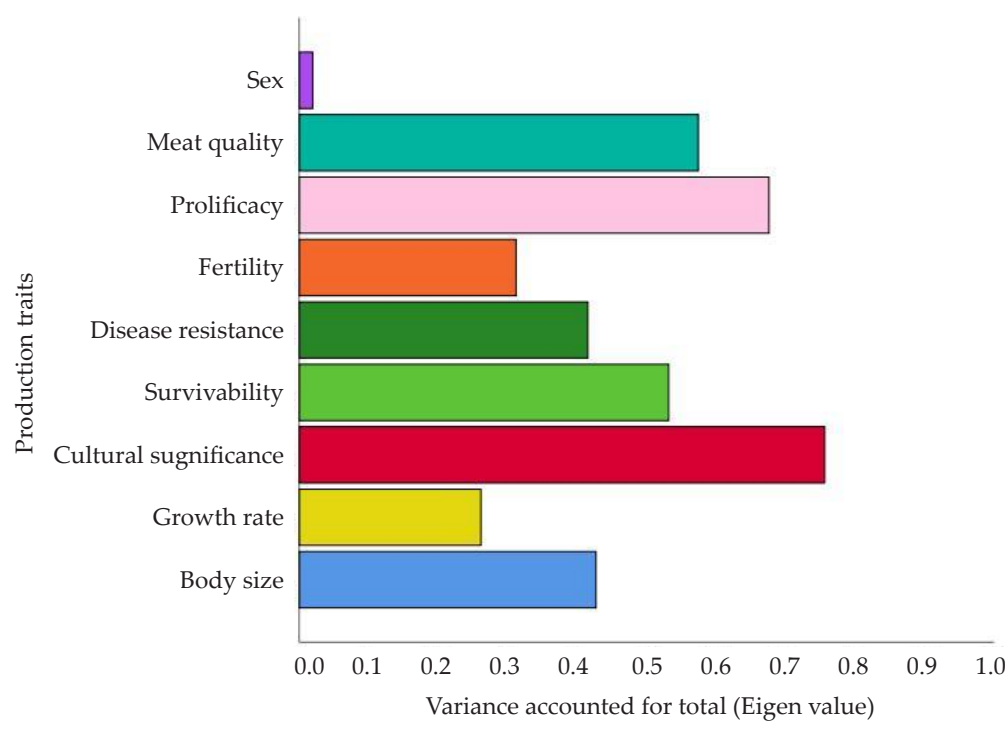

Figure 1. The contribution of each production trait to the total variation

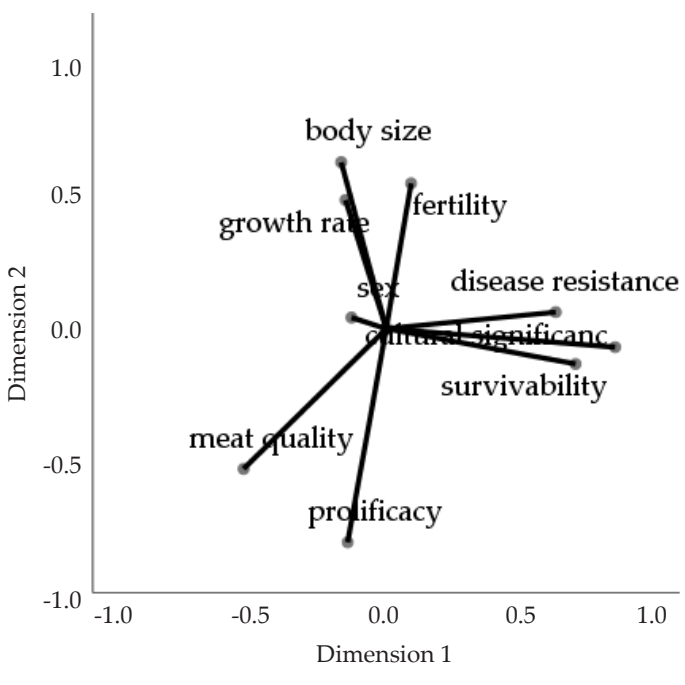

Variable principal normalization Rotation method: Varimax with Kaiser Normalization

Figure 2. Individual production trait loadings on the principal components farmers. Sheep are known to play a veritable role in the study area as animals of preference during 'Eid al-Kabir' religious festival. They are also used during naming and other socio-cultural ceremonies, and by traditionalists as a sacrifice to the deities. This is in concordance with the submission of Dossa et al. (2015).

Concerning traits of preference for breeding, both sexes equally emphasized body size, body conforma- tion, mothering ability, disease resistance, survivability, heat tolerance (adaptive), fertility, and temperament. It is a reflection of the premium attached to productive and reproductive parameters by male and female farmers since they are known to be directly or indirectly related to farm income. This is consistent with the report of Roessler et al. (2008) in a related study where productive and reproductive criteria were accorded 


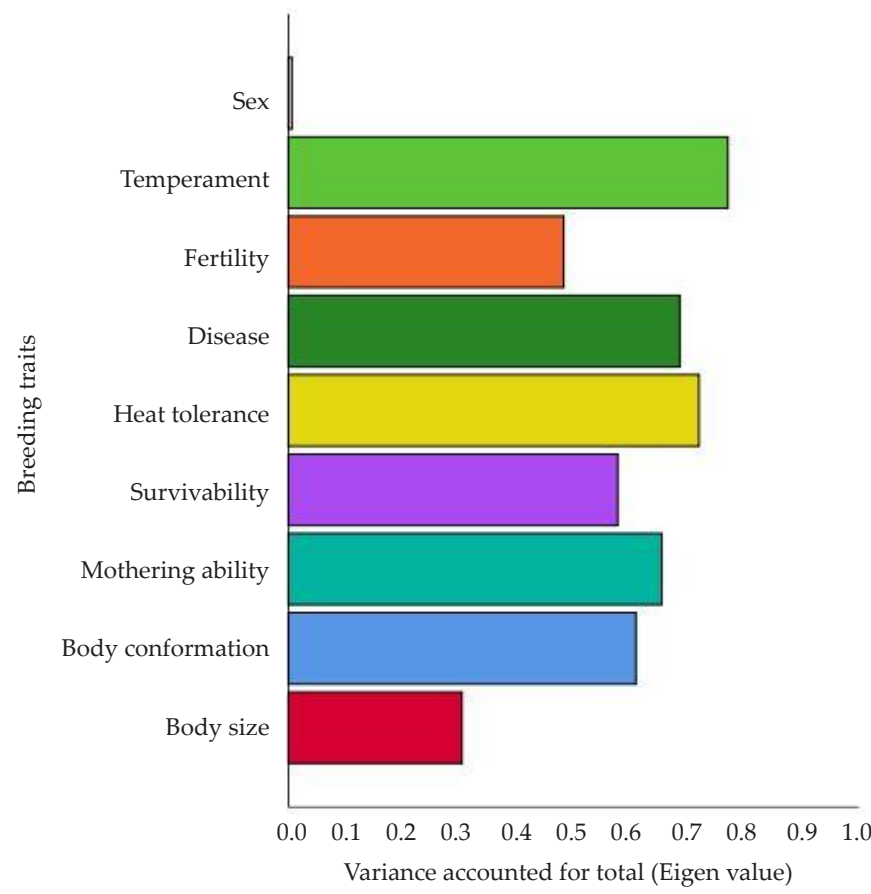

Figure 3. The contribution of each breeding trait to the total variation

utmost importance by the farmers. The set of criteria adopted in this study is similar to size and fertility traits reported for sheep kept by smallholder farmers in Ethiopia (Edea et al., 2012; Nigussie, et al., 2013) and Marshall et al. (2016) in Somalian sheep. Oseni et al. (2017) also reported a high growth rate, high fertility rate, and reproductive performance as important traits in small ruminants in Nigeria while Matebesi-Ranthimo et al. (2018) stressed on ewe reproduction traits in South African sheep. The higher rating of disease resistance by male farmers is congruous to the submission of Marshall et al. (2016) where the trait was rated low by the female sex as a selection criterion for breeding rams and ewes.

From the CATPCA and concerning production traits, the sheep keepers can be clustered into two: those who were more interested in the cultural/ religious relevance and well-being as well as those that emphasized productivity of sheep. As regards the breeding traits, farmers could also be categorized into two: Those that emphasized the general well-being and fertility of sheep as well as those that prioritized the appearance and survival of the animals. Livestock improvement programs may target such categories of farmers to increase sheep production. It was difficult to compare our CATPCA findings based on the sex of farmers with other studies due to the dearth of literature especially on traits' preferences in sheep reared in SubSaharan Africa. However, there is a report on the use of this procedure to assign farmers into groups based on certain performance parameters and non-genetic factors (Martin-Collado et al., 2015; Houessou et al., 2019).

\section{CONCLUSION}

There were variations in the breeding practices (flock structure, breeding control, and access to

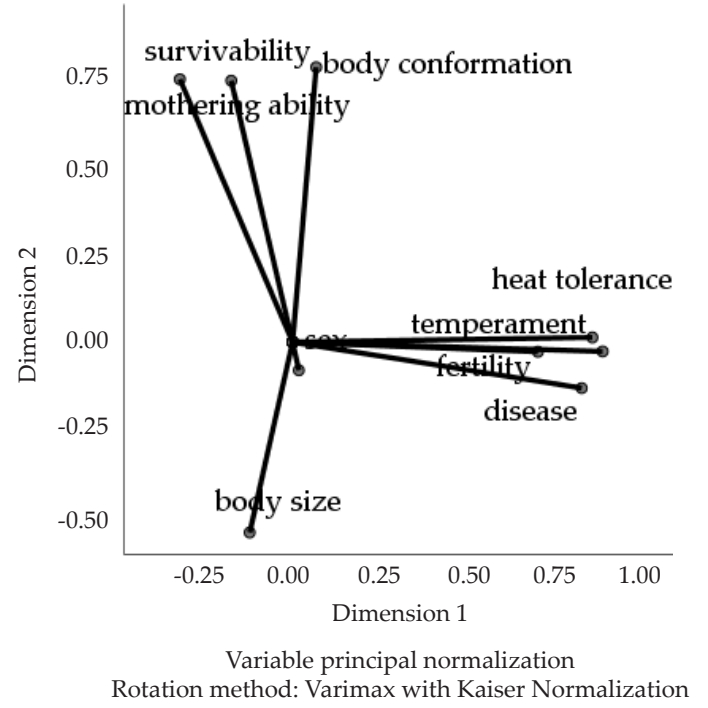

Figure 4. Individual breeding trait loadings on the principal components

veterinary services), the average life span of sheep between male and female farmers. However, both sexes did not significantly differ in the ranking of production objectives including preferences for production and breeding traits. The categorical principal component analysis also revealed little influence of sex of farmers on the traits of preference. The observed variations in the present study might be exploited in improving management strategies to boost sheep production.

\section{CONFLICT OF INTEREST}

The authors declare that that there is no conflict of interest with any financial, personal, or other relationships with other people or organizations related to the material discussed in the manuscript.

\section{ACKNOWLEDGEMENT}

The authors would like to express their immense gratitude to all farmers that participated in the research and the various village heads and extension staff of the Nasarawa Agricultural Development Program (NADP) for facilitation.

\section{REFERENCES}

Aldosari, F. O. 2018. Gender participation in sheep and goat farming in Najran, Southern Saudi Arabia. Saud J. Biol. Sci. 25:144-148. https://doi.org/10.1016/j.sjbs.2017.03.013

Amare, T., G. Goshu, \& B. Tamir. 2018. Flock composition, breeding strategies and farmers'traits of interest evaluation of Wollo highland sheep and their F1 crosses. J. Anim. Sci. Tech. 60:14. https://doi.org/10.1186/s40781-018-0173-9

Anwar, M., N. Ashraf, N. Shafi, M.S. Awan, \& M. Sarwar. 2019. Socio-economics and livestock grazing pattern in and around grey goral habitat in Machiara National Park, Azad Jammu and Kashmir, Pakistan. The J. Anim. Plant Sci. 29: 1142-1149.

Bohan, A., L. Shalloo, P. Creighton, \& T.M. Boland. 2017. A survey of management practices and flock performance and their association with flock size and ewe breed type on Irish sheep farms. The J. Agric. Sci. 155:1332-1341. https:// 
doi.org/10.1017/S0021859617000399

Boogaard, B. K., E. Waithanji, E. J. Poole, \& J-J. Cadilhon. 2015. Smallholder goat production and marketing: a gendered baseline study from Inhassoro District Mozambique. NJAS-Wag. J. Life Sci. 74-75: 51-63. https://doi.org/10.1016/j. njas.2015.09.002

CIOMS. 2002. International Ethical Guidelines for Biomedical Research Involving Human Subjects Prepared by the Council for International Organizations of Medical Sciences (CIOMS) in collaboration with the World Health Organization (WHO), Geneva. p. 62.

Dossa, L. H., M. Sangaré, A. Buerkert, \& E. Schlecht. 2015. Production objectives and breeding practices of urban goat and sheep keepers in West Africa: regional analysis and implications for the development of supportive breeding programs. Springer Plus 4:281. https://doi.org/10.1186/ s40064-015-1075-7

Edea, Z., A. Haile, M. Tibbo, A. K. Sharma, J. Sölkner, \& M. Wurzinger. 2012. Sheep production systems and breeding practices of smallholders in western and south-western Ethiopia: Implications for designing community-based breeding strategies. Livest. Res. Rur. Devel., 24, Article \#117. http://www.lrrd.org/lrrd24/7/edea24117.htm [11 September 2018]

FAOSTAT. 2017. Food and Agriculture Organization of the United Nations. FAOSTAT Database on Agriculture. Rome, Italy. http://faostat.fao.org/default.aspx. [22 October 2019]

FSNAU-Somalia. 2012. Gender in Emergency Food Security, Livelihoods and Nutrition in Somalia. Food Security and Nutrition Analysis Unit - Somalia, Food and Agricultural Organisation of the United Nations, Rome, Italy.

Karmebäck, V.N., J.N. Wairore, M. Jirström, \& G. Nyberg. 2015. Assessing gender roles in a changing landscape: diversified agro-pastoralism in drylands of West Pokot, Kenya. Pastoralism: Res. Pol. Pract. 5: 21. https://doi.org/10.1186/ s13570-015-0039-4

Getachew, T., A. Haile, M. Tibbo, A.K. Sharma, J. Sölkner, \& M. Wurzinger. 2010. Herd management and breeding practices of sheep owners in a mixed crop-livestock and a pastoral system of Ethiopia. Afr. J. Agric. Res. 5: 685- 691.

Gizaw, S., T. Getachew, Z. Edea, T. Mirkena, G. Duguma, M. Tibbo, B. Rischkowsky, A.M. Okeyo, T. Dessie, M. Wurzinger, J. Solkner, \& A. Haile. 2013. Characterization of indigenous breeding strategies of the sheep farming communities of Ethiopia: A basis for designing community-based breeding programs. ICARDA working paper, Aleppo, Syria. p. 47.

Houessou, S. O., L.H. Dossa, R. V. C. Diogo, M. Houinato, A. Buerkert, \& E. Schlecht. 2019. Change and continuity in traditional cattle farming systems of West African Coast countries: A case study from Benin. Agric. Syst. 168:112122. https://doi.org/10.1016/j.agsy.2018.11.003

Kosgey I. S., G. J. Rowlands, J. A. M. Van Arendonk, \& R. L. Baker. 2008. Small ruminant production in smallholder and pastoral/extensive farming systems in Kenya. Small Rumin. Res. 77: 11-24. https://doi.org/10.1016/j. smallrumres.2008.02.005

Lyam, A. 2000. Nasarawa State. In: Mamman, A.B., Oyebanji, J.O. and Peters, S.W. (Eds). Nigeria: A People United, a Future Assured. Survey of States, Vol. 2, Federal Ministry of Information, Abuja.

Marshall, K., N. Mtimet, F. Wanyoike, N. Ndiwa, H. Ghebremariam, L. Mugunieri, \& R. Costagli. 2016. Traditional livestock breeding practices of men and women Somali pastoralists: trait preferences and selection of breeding animals. J. Anim. Breed. Genet. 133: 534-547. https://doi.org/10.1111/jbg.12223

Marshall, K., N. Mtimet, F. Wanyoike, \& N. Ndiwa. 2014. The complex and gender differentiated objectives of livestock keeping for Somali pastoralists. Proceedings of the 10th World Congress of Genetics Applied to Livestock Production. Vancouver, Canada. pp. 17-22.

Martin-Collado, D., T.J. Byrne, P.R. Amer, M.J. Behrent, G. MacLennan and J.I. Kerslake. 2015. Analysing hidden patterns of farmers' preferences for farm performance characteristics that may be related to tail-docking practice decisions. Proceedings of the New Z. Soc. Anim. Prod. 75: 205-209

Mataveia, G. A., C. M. L. P. Garrine, A. Pondja, A. Hassen, \& C. Visser. 2018. Smallholder goat production in the Namaacha and Moamba districts of southern Mozambique. J. Agric. Rural Devel. Trop. Subtrop. 119: 31-41.

Matebesi-Ranthimo, P. A. M., S. W. P. Cloete, J. B. van Wyk, \& J. J. Olivier. 2018. Relationship of ewe reproduction with subjectively assessed wool and conformation traits in the Elsenburg Merino flock. S. Afr. J. Anim. Sci. 48:29-38. https://doi.org/10.4314/sajas.v48i1.4

Nigussie, H., Y. Mekasha, K. Kebede, S. Abegaz, \& P. S. Kumar. 2013. Production objectives, breeding practices and selection criteria of indigenous sheep in eastern Ethiopia. Livest. Res. Rur. Devel., 25, Article \#157. http://www.lrrd. org/lrrd25/9/nigu25157.htm . [11 September 2018]

Oseni, S.O., A. Yakubu, \& A. R. Aworetan. 2017. Nigerian West African Dwarf goats. In: Simões, João, Gutiérrez, Carlos (Eds.). Sustainable Goat Production in Adverse Environments: Vol. 2. Springer International Publishing AG, Gewerbestrasse 11, Switzerland. pp. 91-110. https:// doi.org/10.1007/978-3-319-71294-9_8

Parmawati, R., Mashudi, A. Budiarto, Suyadi, \& A. S. Kurnianto. 2018. Developing sustainable livestock production by feed adequacy map: a case study in Pasuruan, Indonesia. Trop. Anim. Sci. J. 41: 67-76. https://doi. org/10.5398/tasj.2018.41.1.67

Roessler, R., A. G. Drucker, R. Scarpa, A. Markemann, U. Lemke, L.T. Thuy, \& A. Valle Zárate. 2008. Using choice experiments to assess smallholder farmers' preferences for pig breeding traits in different production systems in North-West Vietnam. Ecol. Econ. 66:184-192. https://doi. org/10.1016/j.ecolecon.2007.08.023

SPSS. 2015. Statistical Package for Social Sciences. SPSS Inc., 444 Michigan Avenue, Chicago, IL60611.

Tabbaa, M. J. \& R. Al-Atiyat. 2009. Breeding objectives, selection criteria and factors influencing them for goat breeds in Jordan. Small Rumin. Res. 84:8-15. https://doi.org/10.1016/j. smallrumres.2009.03.007

Tadesse, Y., M. Urge, S. Abegaz, M.Y. Kurtu, K. Kebede, \& T. Dessie. 2014. Husbandry, breeding practices, and production constraints of camel in the pastoral communities of Afar and Somali, Ethiopia. J. Agric. Environ. Int. Devel. 108:167-189.

Vargas, B., A. F. Groen, M. Herrero, \& J. A. M. Van Arendonk. 2002. Economic values for production and functional traits in Holstein cattle of Costa Rica. Livest. Prod. Sci. 75:101116. https://doi.org/10.1016/S0301-6226(01)00305-0

Wurzinger, M., L. Escareno, F. Pastor, H. Salinas-Gonzalez, L. Iniguez, \& J. Solkner. 2013. Design and implementation of a community-based breeding program for dairy goats in northern, Mexico. Trop. Subtrop. Agroecosyst. 16:289-296.

Yakubu, A., L. Dahloum, \& E. G. Gimba. 2019. Smallholder cattle farmers' breeding practices and trait preferences in a tropical guinea savanna agro-ecological zone. Trop. Anim. Health Prod. 51: 1497-1506. https://doi.org/10.1007/ s11250-019-01836-y

Yakubu, A. \& M. M. Achapu. 2016. Assessment of production objective and breeding practices of rural goat keepers and implications for a breeding program in north central Nigeria. Niger. J. Anim. Prod. 44: 50-61. 